\title{
Identification, Secretion, and Neural Expression of APPL, a Drosophila Protein Similar to Human Amyloid Protein Precursor
}

\author{
Liqun Luo, Linda E. Martin-Morris, and Kalpana White \\ Department of Biology, Brandeis University, Waltham, Massachusetts 02254
}

\begin{abstract}
A Drosophila gene [amyloid protein precursor-like (Appl)] has recently been identified whose predicted amino acid sequence (APPL) shares extensive homology with the $\beta$-amyloid protein precursor (APP) associated with Alzheimer's disease. Characterization of proteins encoded by the Appl gene was initiated with the expectation that this simple model system might help elucidate the basic function provided by APPL and APP proteins.
\end{abstract}

In this report, we identify 2 forms of the APPL protein in embryonic extracts, primary cultures, and transfected cells. APPL is synthesized as a 145-kDa membrane-associated precursor that is converted to a 130-kDa secreted form that lacks the cytoplasmic domain. Both forms are N-glycosylated. Pulse-chase and subcellular localization studies suggest that the conversion is very rapid. The similarities of biogenesis between APP and APPL provide further evidence that APPL and APP might be functionally homologous, and that the secretion event is of physiological significance.

Immunocytochemical studies show that the APPL proteins are first detected in developing neurons concomitant with axonogenesis and remain associated with differentiated neurons. APPL immunoreactivity was observed in neuronal cell bodies, axonal tracts, and neuropil regions. In the embryo, APPL proteins are expressed exclusively in the CNS and PNS neurons, consistent with the App/ transcript localization. The expression pattern of APPL proteins suggests an ancestral function for this protein in the nervous system.

Our understanding of the molecular events in the pathogenesis of Alzheimer's disease has been greatly facilitated by the isolation of $\beta$-amyloid protein, a major proteinaceous component of senile plaques (Glenner and Wong, 1984; Masters et al., 1985) and the subsequent cloning of amyloid protein precursor (APP; Goldgaber et al., 1987; Kang et al., 1987; Robakis et al., 1987; Tanzi et al., 1987; for review, see Müller-Hill and Beyreuther,

\footnotetext{
Received May 14, 1990; accepted Aug. 2, 1990.

We thank Steve Robinow for advice during the early phase of this work. We also thank Drs. Sam Gandy and Joseph Buxbaum and all members of the White lab for helpful discussions. We gratefully acknowledge Michael Rosbash's generosity for allowing us to use the tissue culture facilities and the help from Hildur Colot and Marie Laure Samson during the cell culture experiments. We appreciate the comments on this manuscript from Isaac Edry, Pat Parmenter, Michael Rosbash, and Larry Zwiebel. This research was supported by NIH GM-33205 and by an Alzheimer's Disease and Related Disorders grant to K.W. L.M.-M. was supported by NIH Predoctoral Training Grant NS-07292 and NIMH Predoctoral Fellowship MH-09824.

Correspondence should be addressed to Dr. Kalpana White, Department of Biology, Brandeis University, Waltham, MA 02254.
}

Copyright (C) 1990 Society for Neuroscience $0270-6474 / 90 / 123849-13 \$ 03.00 / 0$
1989; Selkoe, 1989). A Drosophila gene, amyloid protein precursor-like ( $\mathrm{Appl})$, has recently been identified whose predicted amino acid sequence (APPL) shares extensive homology with APP throughout the molcculc (Rosen ct al., 1989; Martin-Morris and White, 1990). Both APP and APPL have single-membrane-spanning domains near their respective carboxyl termini. Notable features of the homology between APP and APPL include 2 highly conserved regions in the extracellular domain, $\mathrm{E} 1$ and E2. There are 12 cysteine residues conserved in the E1 region and a conserved $\mathrm{N}$-glycosylation site in the $\mathrm{E} 2$ region. $\mathrm{A}$ highly conserved cytoplasmic domain was also observed between APP and APPL, with a stretch of 15 amino acids containing 13 identities in the carboxyl terminus. However, there is no significant primary sequence homology in the transmembrane domain or in the extracellular domain near the membrane-spanning region; therefore, the $\beta$-amyloid sequence, which spans the border of extracellular and transmembrane domains of APP, is not found in APPL.

The mammalian APP is expressed in many tissues and encodes a family of proteins consisting of several isoforms, some of which contain an additional protease inhibitor domain (Kitaguchi et al., 1988; Ponte et al., 1988; Tanzi et al., 1988). They appear to be generated by alternative splicing (Kitaguchi et al., 1988; Ponte et al., 1988; Tanzi et al., 1988; de Sauvage and Octave, 1989), as well as by further processing of primary polypeptides (Weidemann et al., 1989). In contrast, only a singlesize transcript has been found in Drosophila, which is expressed in a neural-specific manner as determined by Northern and in situ hybridization analysis (Rosen et al., 1989; Martin-Morris and White, 1990). Characterization of APPL protein was initiated with the expectation that this simple model system might help elucidate the basic function provided by this class of molecules.

By generating polyclonal antibodies against different parts of APPL, we have identified 2 forms of APPL in Drosophila embryos, embryonic primary cultures, and transfected Schneider cells: a $145-\mathrm{kDa}$ membrane-associated form and a $130-\mathrm{kDa}$ secreted form. We have shown in cell culture studies that the $145-\mathrm{kDa}$ form is a precursor form that is rapidly transformed to the $130-\mathrm{kDa}$ secreted form, and that both forms are N-glycosylated. Furthermore, immunocytochemical studies demonstrate that APPL is expressed in differentiated neurons, and that the subcellular localization of APPL is consistent with biochemical data. Our results provide further evidence that APP and APPL might be functionally homologous in their respective organisms and suggest an ancestral nervous system function for this class of molecules.

Some of the data presented here have been reported previously in brief form (Luo et al., 1989). 


\section{Materials and Methods}

Plasmid constructions. The vector for constructing the T7-fusion protein pGDD7 $\mathrm{E}$ was a gift from Dr. M. Palazzolo (California Institute of Technology). To make the T7-APPL fusion, cDNA c4 (Rosen et al., 1989 ) in Bluescript SK ${ }^{+}$vector (Stratagene) was digested with Hind III and Xba I and ligated to Hind III and Xba I-digested pGDD7,E. A single Not I site at the polylinker was cut, filled in, and religated to align the T7 coat protein and APPL in frame. To make T7-APPL ${ }^{2}$, oligodirected mutagenesis was used to change nucleotide 2477 of $A p p l$ (Rosen et al., 1989) from $T$ to $C$, to create a Not I site on the c4-pGDD7 $E$ hybrid plasmid described above. The plasmid was cut with Not $I$ and religated to delete the extracellular domain. Both junctions were verified by sequencing.

To make the $\beta$-gal-APPL' fusion protein, $\mathrm{cDNA} c 4$ was cloned into the plasmic pUR 288 (provided by Dr. B. Müller-Hill) EcoRI site, which would generate an in-frame fusion of $\beta$-galactosidase-APPL ${ }^{\prime}$ fusion protein.

To make the hsp-Appl construct, a 5.5-kb Appl cDNA (S2) was inserted into the EcoRI site of a plasmid containing the hsp 70 promoter and $\beta$-tubulin polyadenylation site (provided by Dr. J. Lis). This construct contains the entire open reading frame (ORF) of $\mathrm{Appl}$, and its oricntation was confirmed by restriction analysis.

Antibody generation and affinity purification. The T7-APPL ${ }^{1}$ and T7$\mathrm{APPL}^{2}$ constructs were used to transform $E$. coli strain Bal 21-pLysS (provided by Dr. F. W. Studier). IPTG (final concentration, $1 \mathrm{~mm}$ ) was added to $500 \mathrm{ml}$ of bacterial culture with an $\mathrm{OD}_{550}$ of 0.5 . After $2 \mathrm{hr}$ of induction, cells were collected by $1000 \times \mathrm{g}$ spin, and the pellet was resuspended in $40 \mathrm{ml} 50 \mathrm{~mm}$ Tris $(\mathrm{pH}, 8.0) / 2 \mathrm{~mm}$ EDTA. After freezethawing, the cells were sonicated $4 \times 15 \mathrm{sec}$ and centrifuged at 13,000 $\times g$ for $15 \mathrm{~min}$. The insoluble T7-fusion proteins in the pellet were resuspended in $2 \mathrm{ml} 50 \mathrm{~mm}$ Tris $(\mathrm{pH}, 8.0) / 2 \mathrm{~mm}$ EDTA plus $3 \mathrm{ml}$ of 2 $\times$ sample buffer (Harlow and Lane, 1988) and loaded on $7.5 \%$ preparative SDS-PAGE gels. Induced fusion proteins were excised from the gels and electroeluted into the protein running buffer (Harlow and Lane, 1988 ) at $400 \mathrm{~V}$ for $1 \mathrm{hr}$. One hundred twenty-five or $250 \mu \mathrm{g}$ of protein was used to immunize each rat or rabbit, respectively, and the same amount of protein was used for subsequent boosting.

For affinity purification, rat $\alpha$-APPL serum was first passed through an Affi-gel 10 (Bio-Rad) column covalently linked with bacteria total proteins with pUR288 expressing $\beta$-galactosidase. The flowthrough was loaded on the affinity column of purified $\beta$-gal-APPL ${ }^{\prime}$ fusion protein (Rio et al., 1986) covalently linked with Affi-gel 10. The affinity-purification procedure was as described (Harlow and Lane, 1988). Glycine $(0.1 \mathrm{M}, \mathrm{pH} 2.5)$ was used to elute the antibodies from the column.

Preparation of embryonic extracts and embryonic primary cultures. Unless otherwise mentioned, embryonic extracts were prepared according to the following procedure. After dechorionation in $50 \% \mathrm{Clo}-$ rox, staged embryos (at $25^{\circ} \mathrm{C}$ ) were homogenized in a Dounce homogenizer on ice in PBS (Harlow and Lane, 1988) supplemented with $0.5 \%$ NP-40, $1 \mathrm{~mm}$ EGTA, $0.5 \mu \mathrm{g} / \mathrm{ml}$ leupeptin, $1 \mu \mathrm{g} / \mathrm{ml}$ pepstatin, $100 \mathrm{KIU} /$ $\mathrm{ml}$ aprotinin, and $0.2 \mathrm{mM}$ PMSF. The homogenate was centrifuged for $5 \mathrm{~min}$ at $1000 \times \mathrm{g}$, and the supernatant was collected.

For fractionation of embryonic extracts, dechorionated embryos were homogenized in $1 / 10 \times$ PBS supplemented with 1 mM EGTA and protease inhibitors as above (no detergent). The homogenate was centrifuged for $5 \mathrm{~min}$ at $1000 \times \mathrm{g}$, and the supernatant was further centrifuged at $40,000 \times g$ for $1 \mathrm{hr}$. The supernatant was regarded as the soluble fraction. The pellet was resuspended in PBS supplemented with $2 \% \mathrm{NP}-40$, the resuspended part was centrifuged again, and the supernatant was regarded as the membrane fraction.

Fractionation of S2-Appl cells into soluble and membrane fractions were modified after Simon et al. (1989). S2-Appl cells were heat-shocked for $20 \mathrm{~min}$ and rested at room temperature for $40 \mathrm{~min}$. Cells were pelleted and washed with cold PBS, and the cell pellet was frozen in $-70^{\circ} \mathrm{C}$. After thawing the cells in $1 / 10 \times$ PBS (hypotonic) supplemented with $1 \mathrm{~mm}$ EGTA and protease inhibitors $(0.5 \mu \mathrm{g} / \mathrm{ml}$ leupeptin, $1 \mu \mathrm{g} /$ $\mathrm{ml}$ pepstatin, $100 \mathrm{KIU} / \mathrm{ml}$ aprotinin, $0.2 \mathrm{mM}$ PMSF) and extraction in Dounce homogenizer, samples were spun at $1000 \times \mathrm{g}$ for $5 \mathrm{~min}$, and the supernatants were centrifuged at $40,000 \times g$ for $30 \mathrm{~min}$. The supernatant of this spin was regarded as the soluble fraction. The pellet was resuspended in PBS with protease inhibitors as above, supplemented with $2 \%$ NP- 40 . The extraction was subsequently centrifuged at $12,000 \times g$ for $15 \mathrm{~min}$, and the solubilized supernatant was regarded as the membrane fraction.
Preparation of primary cultures from embryos was modified from the procedures of Wilcox (1986) and Kidd et al. (1989). Staged embryos were dechorionated, washed, and homogenized in $10 \times$ vol M3 media (Harvard Biolab) in Dounce homogenizer with 4 strokes. The homogenate was passed through 3 layers of Nitex $(35-\mu \mathrm{m}$ mesh) and spun for 5 min at $500 \times g$ at $4^{\circ} \mathrm{C}$. The cell pellet was washed twice in M3 media and, finally, resuspended at a density of $10^{8} \mathrm{cells} / \mathrm{ml}$ in Corning cell wells. For metabolic labeling, (met, cys)-free M3 media (Harvard Biolab) was used instead of complete M3 media during extraction. After plating the cells in the culture wells $\left(10^{7}\right.$ cells $\left./ \mathrm{ml}\right)$, cells were given a $45-\mathrm{min}$ starvation before adding $\operatorname{Tran}^{35} \mathrm{~S}$ label (ICN) at $500 \mu \mathrm{Ci} / \mathrm{ml}$ for $2 \mathrm{hr}$ before immunoprecipitation analysis (see below).

Protein gel electrophoresis and immunoblot. Unless otherwise mentioned, all protein gels were 7.5\% SDS-PAGE gels. For immunoblotting, gels were electrotransferred onto nitrocellulose with standard procedures (Harlow and Lane, 1988) overnight at a current of $150 \mathrm{~mA}$. Immunoreaction was visualized using alkaline phosphatase reaction with Promega's Western-blotting system. All the antibody reaction steps were according to manufacturer's specifications (Promega).

Transfection, metabolic labeling, and glycosylation. Transfection of Schneider cells with hsp-Appl was according to Rio and Rubin (1985). Two $\mathrm{d}$ after transfection, the transfected cultures were heat-shocked for $20 \mathrm{~min}$ at $37^{\circ} \mathrm{C}$ and rested at room temperature (RT) for $40 \mathrm{~min}$. Cells were collected by centrifugation. After washing with PBS, the cell pellet was resuspended in an equal vol PBS and $2 \times$ SDS sample buffer and boiled for $5 \mathrm{~min}$ before SDS-PAGE/immunoblot analysis.

For metabolic labeling, cells were heat-shocked at $37^{\circ} \mathrm{C}$ for $20 \mathrm{~min}$, collected from culture dishes, and centrifuged at $500 \times g$ for $5 \mathrm{~min}$. The cell pellet was washed twice with (met, cys)-free M3 media and, finally, resuspended in (met, cys)-free media at a density of $2 \times 10^{6}$ cells $/ \mathrm{ml}$. After $30 \mathrm{~min}$ starvation at RT, Tran ${ }^{35} \mathrm{~S}$ label (ICN) was added at a specific activity of $500 \mu \mathrm{Ci} / \mathrm{ml}$. Cells were labeled for $1 \mathrm{hr}$, then collected into microfuge tubes in which media and cells were fractionated by centrifugation. After washing with M3 media, cells were lysed in PBS with $1 \%$ SDS and boiled for $3 \mathrm{~min}$, and NP-40 was added to $3 \%$ for immunoprecipitation. Media from the labeling was treated in the same way (SDS added to $1 \%$, boiled, and NP-40 added to $3 \%$ ).

For the pulse-chase labeling experiment, the procedures were basically as above, except that, after $10 \mathrm{~min}$ of labeling with $\operatorname{Tran}^{35} \mathrm{~S}$ label at a specific activity of $1 \mathrm{mCi} / \mathrm{ml}$ in $50-\mathrm{ml}$ Falcon tubes, complete $\mathrm{M} 3$ media was added, and cells were pelleted and resuspended in complete M3 media. Cell suspension aliquots of $300 \mu \mathrm{l}$ were incubated in Eppendorf tubes for various times at RT $\left(23^{\circ} \mathrm{C}\right)$. Further treatment was identical to the metabolic labeling procedure described above. Immunoprecipitation was performed as described below.

For the glycosylation experiment, tunicamycin was added at a concentration of $10 \mu \mathrm{g} / \mathrm{ml}$ from the start of heat-shock $\left(37^{\circ} \mathrm{C}, 20 \mathrm{~min}\right)$ and through the starvation (RT, $30 \mathrm{~min}$ ) and labeling (RT, $2 \mathrm{hr}$ ) period.

Immunoprecipitation. For immunoprecipitation of labeled proteins, samples were precleared by incubating with $20 \mu \mathrm{l} \mathrm{GammaBind} \mathrm{G-Aga-}$ rose (Genex Corporation) in PBS for $30 \mathrm{~min}$ at $4^{\circ} \mathrm{C}$ and spun at 12,000 $\times g$ for $2 \mathrm{~min}$. The recovered supernatant was incubated with $10 \mu \mathrm{l}$ rat $\alpha$-APPL serum for $1 \mathrm{hr}$ at $4^{\circ} \mathrm{C}$, and $20 \mu \mathrm{l}$ of GammaBind G-Agarose was added for a further incubation of $30 \mathrm{~min}$ at $4^{\circ} \mathrm{C}$. The immunoprecipitated complex was first washed with PBS supplemented with $0.5 \%$ Triton, then twice with PBS. The final pellet was resuspended in $2 \times$ sample buffer and subjected to SDS-PAGE. Subsequent fixing and amplification were according to manufacturer's specification (Amersham). Amplified gels were dried and exposed to Kodak x-ray film.

For immunoprecipitation of embryonic extracts (see Fig. 3A), the procedure was essentially the same as above. One mg of total proteins was used in each immunoprecipitation reaction. The SDS-PAGE gel was transferred to nitrocellulose, and the immunoblot reaction was carried out as described above.

Immunocytochemistry. Whole-mount embryo staining was performed according to Thomas et al. (1988). Devitellinized embryos were rehydrated through a methanol series and incubated in PBT $(0.1 \mathrm{M}$ sodium phosphate buffer, pH 7.2 , with $0.3 \%$ Triton) with $5 \%$ normal goat serum for $2 \mathrm{hr}$ at RT. The primary antibody reaction was carried out at $4^{\circ} \mathrm{C}$ overnight, and Vector $\mathrm{ABC}$ kit was followed for subsequent steps.

For larval-brain and eye-disk staining, hand-dissected third-instar larval brains and disks were fixed in $4 \%$ paraformaldehyde overnight, washed in PBT twice for $5 \mathrm{~min}$, washed once in methanol for $15 \mathrm{~min}$, washed twice for $5 \mathrm{~min}$ in PBT, and incubated for $2 \mathrm{hr}$ in PBT with 
A

\section{Extracellular}

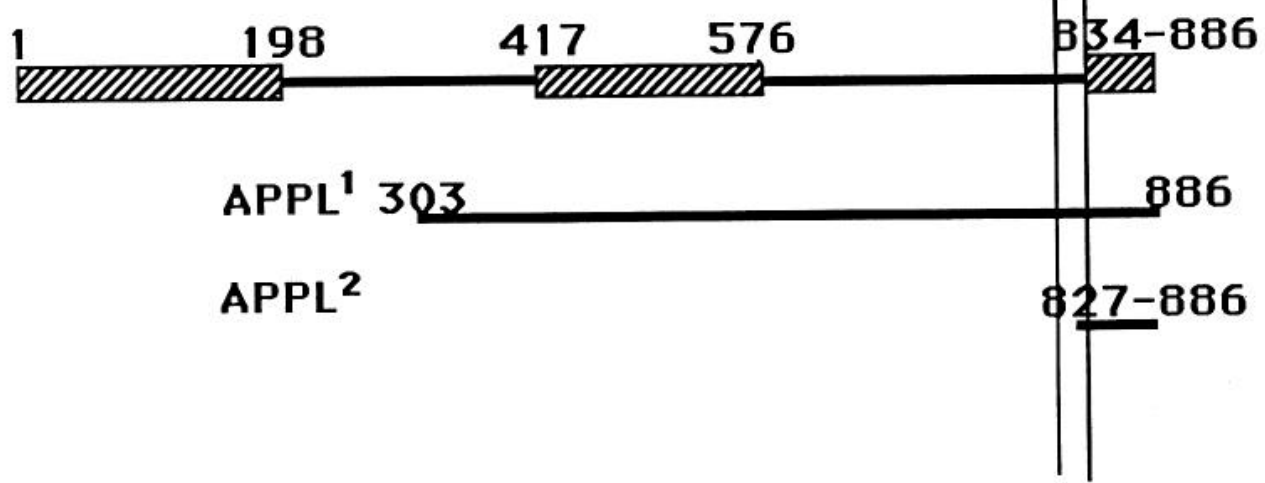

B

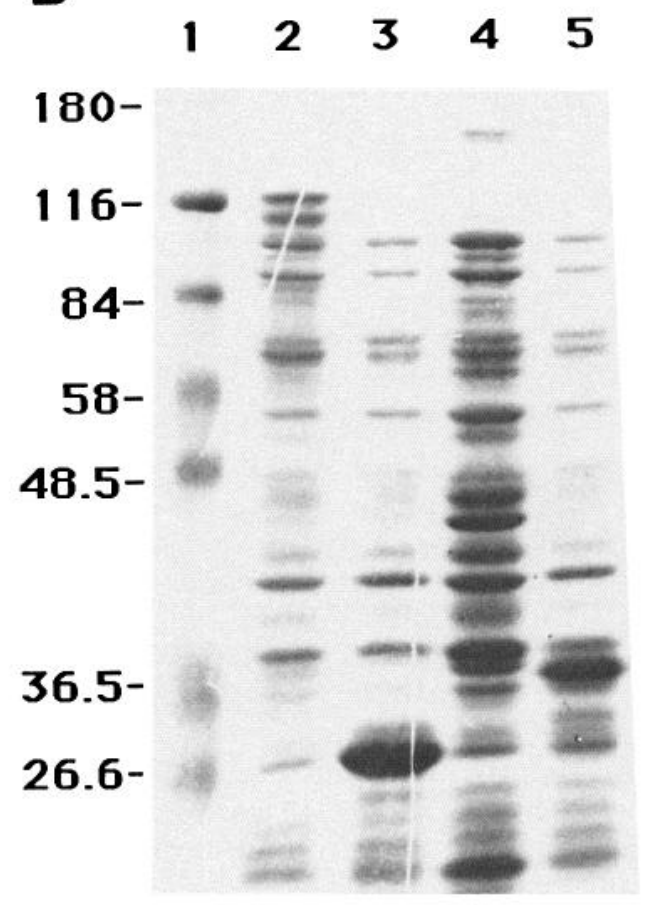

Figure 1. Generation of fusion proteins. $A$, Schematic drawings of the APPL structure predicted from the primary sequence and portions of the molecule that were used to make fusion proteins for generating antibodies are shown. Hatched bars indicate the 3 regions most homologous to APP. $\mathrm{APPL}^{1}$ and $\mathrm{APPL}^{2}$ represent 2 regions of APPL used to generate T7-fusion proteins. $B$, Coomassie-stained SDSPAGE gels of proteins from bacterial cells expressing different fusion constructs. Lane 1, molecular-weight marker (Sigma); lane 2, induced cells with T7-APPL ${ }^{1}$ fusion construct; the doublet around $116 \mathrm{kDa}$ corresponds to T7-APPL ${ }^{1}$ fusion; lane 3 , induced cells with vector ( $\mathrm{pGDD7} \mathrm{x})$ alone; lane 4 , uninduced cells; lane 5, induced cells with T7-APPL ${ }^{2}$ construct; the novel 37 $\mathrm{kDa}$ band corresponds to T7-APPL ${ }^{2}$ fusion.
$5 \%$ normal goat serum before primary antibody incubation at $4{ }^{\circ} \mathrm{C}$ overnight. Vector ABC kit was followed for subsequent steps.

Some whole-mount immunostained preparations were further embedded in paraffin and sectioned as described (White et al., 1986).

For salivary-gland staining of the transformant lines carrying the hspAppl construct, larvae were collected into Eppendorf tubes and heatshocked at $37^{\circ} \mathrm{C}$ for $20 \mathrm{~min}$, then allowed to rest at RT for $40 \mathrm{~min}$. Salivary glands were dissected, fixed in $4 \%$ paraformaldehyde for $1 \mathrm{hr}$ at RT, washed twice in PBT for $5 \mathrm{~min}$ each, washed once in methanol for $15 \mathrm{~min}$, washed twice for $5 \mathrm{~min}$ in PBT again, and incubated for $30 \mathrm{~min}$ in PBT with $5 \%$ normal goat serum. After primary antibody incubation at $37^{\circ} \mathrm{C}$ for $1 \mathrm{hr}$, samples were washed in PBT $4 \times 5 \mathrm{~min}$, incubated with fluorescein isothiocyanate- (FITC) conjugated goat antirat secondary antibody (Cappel) for $1 \mathrm{hr}$ at $37^{\circ} \mathrm{C}$, washed in PBT $4 \times$
$5 \mathrm{~min}$, and washed once in $4 \mathrm{~mm}$ sodium bicarbonate $(\mathrm{pH}, 9.5)$ for 10 min before mounting.

Fly stocks. All the embryo extracts and primary cell cultures were made from wild-type Canton-S flies that were reared on cornmeal-agarmolasses food at $25^{\circ} \mathrm{C}$.

The deficiency flies used as a negative control for immunostaining in Figure $7 C, D f(1) s r v \cdot D p 24$, were made as an interstitial deletion that uncovers 4 known lethal complementation groups in the genomic interval and $A p p l$ (K. White, unpublished observations). Df(1)srv.Dp24/ + females were crossed to wild-type males to obtain embryos deleted for the Appl genomic region.

To generate the transformants used in the salivary gland staining experiment (see Fig. $8 C, D$ ), the hsp- $A p p l$ construct described above was inserted at the Xba I site into Casper transformation vector (Pirotta, 


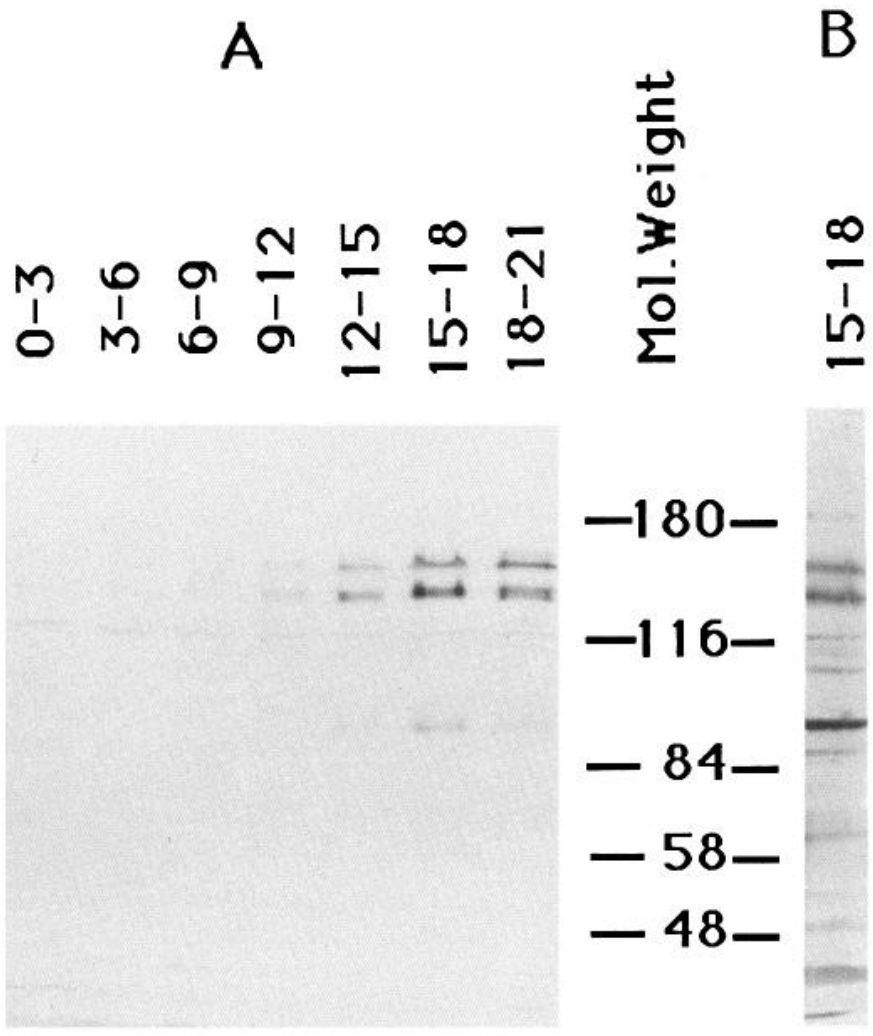

Figure 2. APPL expression during embryonic stages. A, Developmental immunoblot of APPL in embryonic stages probed with affinitypurified $\alpha$-APPL. Protein extracts were made from staged embryos (at $25^{\circ} \mathrm{C}$ ) of 3-hr intervals spanning Drosophila embryogenesis. $B$, Immunoblot of 15-18-hr embryonic extract probed with $\alpha$-APPL serum at a dilution of 1:200.

1988). This DNA was injected into $D f(1)$ white embryos, and independently transformed flies were obtained (Rubin and Spradling, 1982). Two of these lines (one on the second chromosome, the other on the third chromosome) were used to create the double homozygous strain used in the experiment.

\section{Results}

\section{Generation of anti-APPL antiserum}

The Appl ORF predicts an 886-amino acid polypeptide with a putative transmembrane domain near the carboxyl terminus (Fig. 1A). cDNA c4 of $A p p l$, which codes from amino acid residue 303 to the $C$ terminus, was used in a bacterial expression vector system to generate a T7 coat-protein APPL' (T7-APPL $\left.{ }^{1}\right)$ fusion (Studier and Moffat, 1986; Fig. 1A). A fragment of c4, which codes for the cytoplasmic domain along with 7 amino acid residues in the transmembrane domain, was also used in the same expression system to make a T7-APPL fusion (Fig. $1 A)$. Both fusion constructs were used to transform $E$. coli cells allowing for induced expression (see Materials and Methods). Compared to the uninduced cells (Fig. 1B, lane 4), induced bacterial cells bearing the vector alone expressed the T7 coat protein that migrates around $30 \mathrm{kDa}$ (Fig. $1 B$, lane 3 ). Induction of cells bearing the T7-APPL ${ }^{1}$ fusion construct resulted in the expression a doublet of approximately $116 \mathrm{kDa}$ (Fig. $1 B$, lane 2 ), while cells bearing the T7-APPL ${ }^{2}$ construct expressed a novel 37-kDa protein (Fig. 1B, lane 5). These induced proteins were excised from preparative SDS-PAGE gels and used as immu- nogens to inject rats and rabbits. The sera obtained are termed $\alpha$-APPL and $\alpha$-APPL ${ }^{\mathrm{c}}$ (for cytoplasmic domain), respectively.

In both cases, the generation of anti-APPL antibodies was confirmed by immunoblot recognition of a $\beta$-gal-APPL ${ }^{1}$ fusion protein (see Materials and Methods) and immunoprecipitation of the in vitro translated product from an Appl cDNA containing the entire ORF (data not shown). Rat $\alpha$-APPL serum was affinity purified using a $\beta$-gal-APPL ${ }^{1}$ fusion protein column (see Materials and Methods).

\section{APPL occurs as a 145-kDa and a 130-kDa form in late embryogenesis}

To identify APPL protein(s), extracts from staged embryos were analyzed on developmental immunoblots with affinity-purified $\alpha$-APPL (Fig. 2A). Two bands with approximate molecular weights of $145 \mathrm{kDa}$ and $130 \mathrm{kDa}$ correspond to major APPL proteins because (1) these bands show enrichment when probed with affinity-purified antibody compared to serum (cf. Fig. $2 A$ with $2 B$ ); and (2) they are first detected in 9-12-hr embryos and persist thereafter, as would be predicted from the expression pattern of $\mathrm{Appl}$ transcript (Rosen et al., 1989). The 90-kDa band, which has a similar developmental profile and is weakly recognized by affinity-purified antibodies, might represent a degradation product formed during the extraction procedure, as the relative intensity varies between extractions, and it is not seen in extracts from embryonic primary culture and transfected cells (see below). The APPL proteins migrate with apparent molecular weights higher than that predicted from the primary sequence $(98 \mathrm{kDa})$. This is indicative of posttranslational modifications, as will be described below.

\section{The 130-kDa form of APPL lacks the cytoplasmic domain and is secreted into the culture media of primary embryonic cells}

Several lines of evidence in mammalian systems indicate the existence of APP isoforms without the cytoplasmic domain (de Sauvage and Octave, 1989; Palmert et al., 1989; Weidemann et al., 1989). To test if a similar situation exists in Drosophila, immunoprecipitations with $\alpha$-APPL and $\alpha$-APPLC were performed in parallel. Extracts from 10-19-hr embryos were immunoprecipitated with either $\alpha$-APPL or $\alpha$-APPL ${ }^{\mathrm{C}}$ serum. The precipitated proteins were detected on immunoblots using $\alpha$-APPL serum. While $\alpha$-APPL could precipitate both the $130-$ $\mathrm{kDa}$ and the $145-\mathrm{kDa}$ proteins with approximately equal efficiency (Fig. $3 A$, lane 1), $\alpha$-APPLC could only precipitate the 145-kDa protein (Fig. 3A, lanes 2, 3). As a negative control, antiserum generated in the same expression system against another Drosophila protein, ELAV (Robinow et al., 1988; Robinow, 1989), failed to precipitate proteins recognized by $\alpha$-APPL (Fig. 3A, lane 4). Based on these findings, we suggest that the $130-\mathrm{kDa}$ band represents a form of APPL that lacks the cytoplasmic domain.

If the difference between the 2 forms of APPL is solely at the carboxyl terminus, the molecular weight difference between the 2 forms suggests that the $130-\mathrm{kDa}$ form would also lack the membrane-spanning domain and therefore may represent a secreted form. In order to test this possibility, a primary culture system from embryos was developed (see Materials and Methods). Cells dissociated from 11-14-hr embryos and cultured in M3 media continue to synthesize APPL for at least $5 \mathrm{hr}$ as detected by immunoblot analysis or metabolic labeling (data not shown). As shown by a typical time course in Figure $3 B$, 


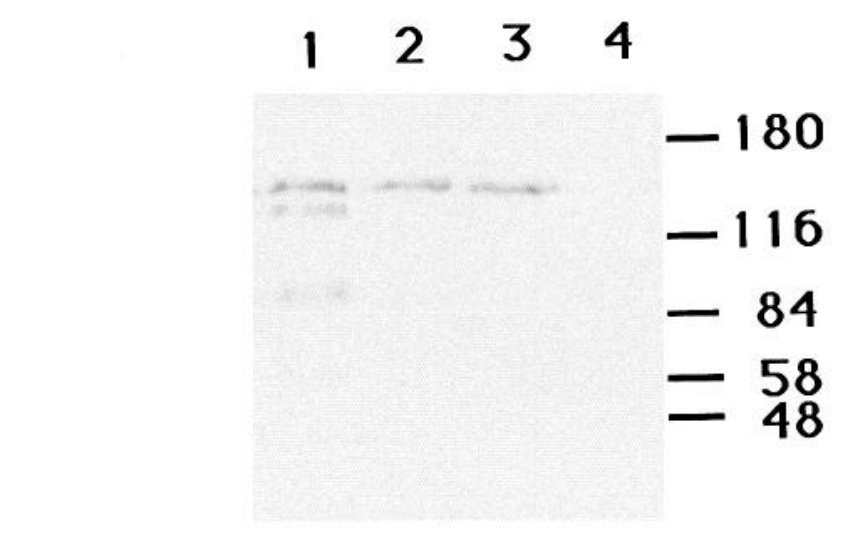

B

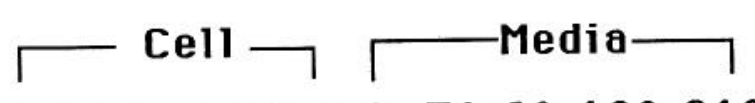

Time (min) $0306012021003060120210 \mathrm{EE}$

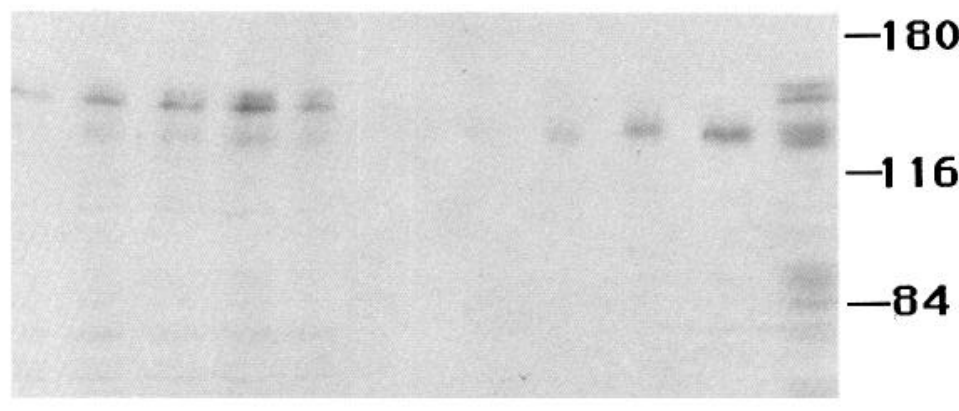

Figure 3. The $130-\mathrm{kDa}$ form lacks cytoplasmic domain and is secreted into culture media of embryonic cells. $A, 10$ 19-hr embryo extracts were immunoprecipitated with rat $\alpha$-APPL serum (lane 1), $\alpha$-APPL ${ }^{\mathrm{C}}$ sera from 2 different rats (lanes 2,3), and rat $\alpha$-ELAV serum (lane 4). The precipitated proteins were run on a $7.5 \%$ SDS-PAGE gel, transferred to nitrocellulose, and probed with rabbit $\alpha$-APPL serum (1:250). $B$, Time course of APPL secretion in primary cell cultures made from 11-14-hr embryos. At different times (min) after the plating of cells in M3 media, equal aliquots were withdrawn. Cells were pelleted. Cell lysates and media supernatants were collected, run on a $7.5 \%$ SDS-PAGE gel, transferred to nitrocellulose, and stained with $\alpha$-APPL serum (1:250). EE, 10-19-hr embryonic extracts. after culturing the cells for various times, cell lysates contain the $145-\mathrm{kDa}$ form and, to a lesser extent, the $130-\mathrm{kDa}$ form. Between 30 and $60 \mathrm{~min}$ after plating, the $130-\mathrm{kDa}$ form is observed in the culture media, and it accumulates thereafter throughout the culture period. This experiment suggests that the $130-\mathrm{kDa}$ cytoplasmic-domain-free form is a secreted form.

\section{A single cDNA transfected into Schneider cells produces both} forms of APPL

There are several likely explanations for the different forms of APPL observed (Fig. 2A). They could result from posttranslational modification of a single polypeptide, they could be generated from alternatively spliced $A p p l$ mRNA, or they could be encoded by separate but homologous genes in Drosophila. To distinguish between these possibilities, we transfected Schneider S2 cells with a construct of Appl cDNA that has the entire ORF of 886 amino acids under the control of heat-shock promoter (see Materials and Methods). By immunoblot analysis, the APPL protein is not detected in nontransfected S2 cells (Fig. 4A, lanes $1,3)$. S2 cells transfected with the hsp-Appl construct (S2-Appl cells), on the other hand, express both the 145-kDa and the 130$\mathrm{kDa}$ forms that comigrate with the forms observed in extracts prepared from embryos (Fig. $4 A$, lanes 2, 4; cf. lane 5). The expression of APPL protein is enhanced by heat-shock treatment (Fig. $4 A$, cf. lane 4 with lane 2). Because only a single cDNA from the Appl locus is used for transfection, the 2 forms must be derived from the same gene. The result is consistent with 2 forms of APPL being different posttranslational modification products, though at this stage, the alternative splicing explanation is not ruled out.

Immunoprecipitation studies of S2-Appl cells labeled with ${ }^{35} \mathrm{~S}$-(met, cys) confirmed the above observations. S2 cells do not express APPL endogenously (Fig. $4 B$, lanes 3, 4, 7, 8). Conversely, in S2-Appl cultures, the $145-\mathrm{kDa}$ APPL could be immunoprecipitated from the lysed cells by $\alpha$-APPL and $\alpha$-APPL ${ }^{c}$ (Fig. $4 B$, lanes 1, 5), while the $130-\mathrm{kDa}$ form could be immunoprecipitated only by $\alpha$-APPL from the media (Fig. $4 B$, lanes 2,6 ) and, to a lesser degree, from the cells (Fig. $4 B$, lane 1). This experiment substantiates the observation in primary cultures that the $130-\mathrm{kDa}$ form is secreted, and that it lacks the cytoplasmic domain.

S2-Appl cells were separated into membrane and soluble fractions by lysing the cells through freeze-thawing and subsequent extraction in hypotonic solution in the absence of detergent (Simon et al., 1989). In this preparation, the $145-\mathrm{kDa}$ form is exclusively present in the membrane fraction (Fig. 4A, lane 6), while the $130-\mathrm{kDa}$ form is predominantly in the soluble fraction (Fig. 4A, lane 7). The underrepresentation of the amount of the $145-\mathrm{kDa}$ band in Figure 4, lane 6 (cf. the ratio between the 145$\mathrm{kDa}$ and the $130-\mathrm{kDa}$ forms in lanes $6,7 \mathrm{vs}$. that in lane 4), is due to the incomplete extraction of the membrane fraction in $2 \%$ NP-40 (see Fig. 4, legend). Fractionation of embryonic ex- 
A

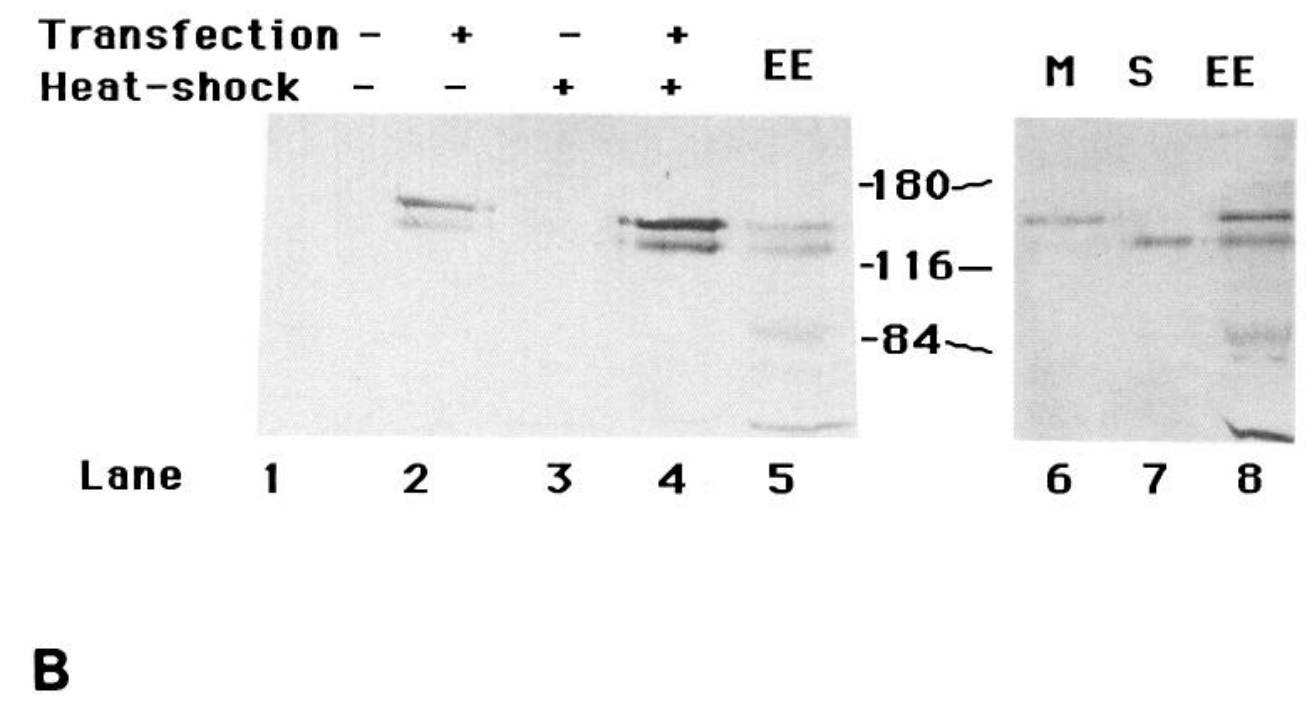

Figure 4. APPL expression and secretion in transfected Schneider cells. $A$, Immunoblot of Schneider cell proteins probed with $\alpha$-APPL serum. Lane 1, S2 cells without heat-shock; lane 2, S2-Appl cells without heat-shock; lane $3, \mathrm{~S} 2$ cells with heat-shock; lane 4, S2-Appl cells with heat-shock; lanes 5 and 8, 10-19hr embryo extract; lane 6, membrane fraction of heat-shocked S2-Appl cells; lane 7 , soluble fraction of heat-shocked S2-Appl cells. The heat-shock regime for the above experiment is $37^{\circ} \mathrm{C}$ for 20 min, RT for $40 \mathrm{~min}$. Samples loaded in lanes 1-4 were from equal number of cells $\left(5 \times 10^{4}\right.$ cells/lane). Lanes 6 and 7 also represent samples from equal number of cells. The amount of the 145$\mathrm{kDa}$ protein in lane 6 is underrepresented due to the incomplete solubilization of the membrane because the pellet of 2\% NP-40 extraction contains the $145-\mathrm{kDa}$ form also (data not shown). $E E, 10-19-\mathrm{hr}$ embryonic extracts. $B$, Immunoprecipitations of ${ }^{35} \mathrm{~S}$-(met, cys)labeled culture. Lanes 1 and 5, S2-Appl cells; lanes 2 and 6, S2-Appl culture media; lanes 3 and 7, S2 cells; lanes 4 and 8 , S2 culture media. Lanes $1-4$ were immunoprecipitated by $\alpha$-APPL, and lanes $5-8$ were immunoprecipitated with $\alpha$-APPLC.

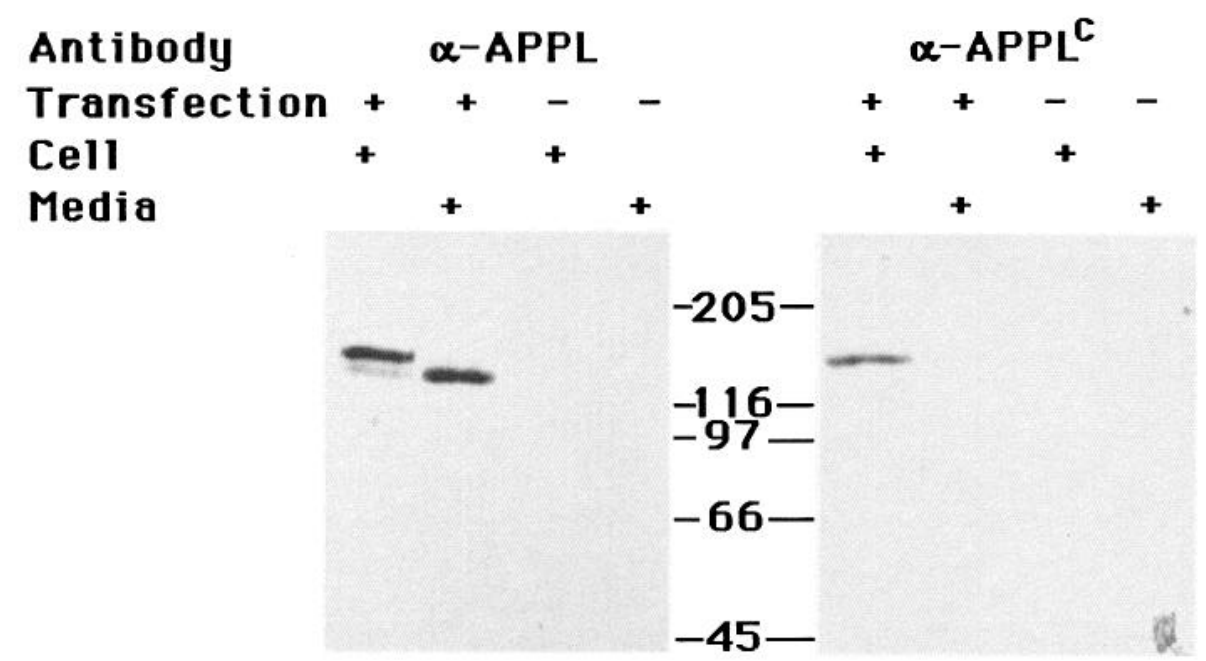

$\begin{array}{lllllllll}\text { Lane } & 1 & 2 & 3 & 4 & 5 & 6 & 7 & 8\end{array}$

tracts by similar procedures generated similar results (data not shown). These experiments suggest that the $145-\mathrm{kDa}$ form represents the 886-amino acid membrane-spanning form predicted from the cDNA ORF.

The 145-kDa membrane-associated form is a precursor that is rapidly converted to the 130-kDa secreted form in S2-Appl cells

In order to establish the relationship between the 2 forms of APPL, pulse-chase labeling experiments were conducted in S2$A p p l$ cells. Heat-shocked S2-Appl cells were given a $10-\mathrm{min}^{35} \mathrm{~S}$ (met, cys) pulse, briefly washed, and further incubated in complete M3 media. Samples from the cell lysates and culture media were collected at $0,10,20,30,60$, and 90 min for immunoprecipitation analysis (Fig. $5 A$ ). During the first 20 -min chase period, the $145-\mathrm{kDa}$ form is observed in the cell lysates, and the amount of radioactivity reaches peak values at $30 \mathrm{~min}$ (Fig. $5 B$ ). After $30 \mathrm{~min}$ chase, the labeled $145-\mathrm{kDa}$ form starts to decline in cell lysates concurrent with the accumulation of the labeled $130-\mathrm{kDa}$ form in the media. By 90 min chase, the majority of the labeled $145-\mathrm{kDa}$ form has been converted into the $130-\mathrm{kDa}$ secreted form. In addition, the rate of appearance of the $130-\mathrm{kDa}$ form is similar to the rate of disappearance of the $145-\mathrm{kDa}$ form, indicating a product-precursor relationship. This experiment strongly suggests that the $145-\mathrm{kDa}$ cell-associated form is the precursor that is converted to the cytoplasmic-domain-free secreted form, presumably by proteolytic cleavage within its extracellular domain. From the size difference, the cleavage site might be close to the membrane-spanning domain. Moreover, the kinetics suggest that the conversion is a rapid event. 
A
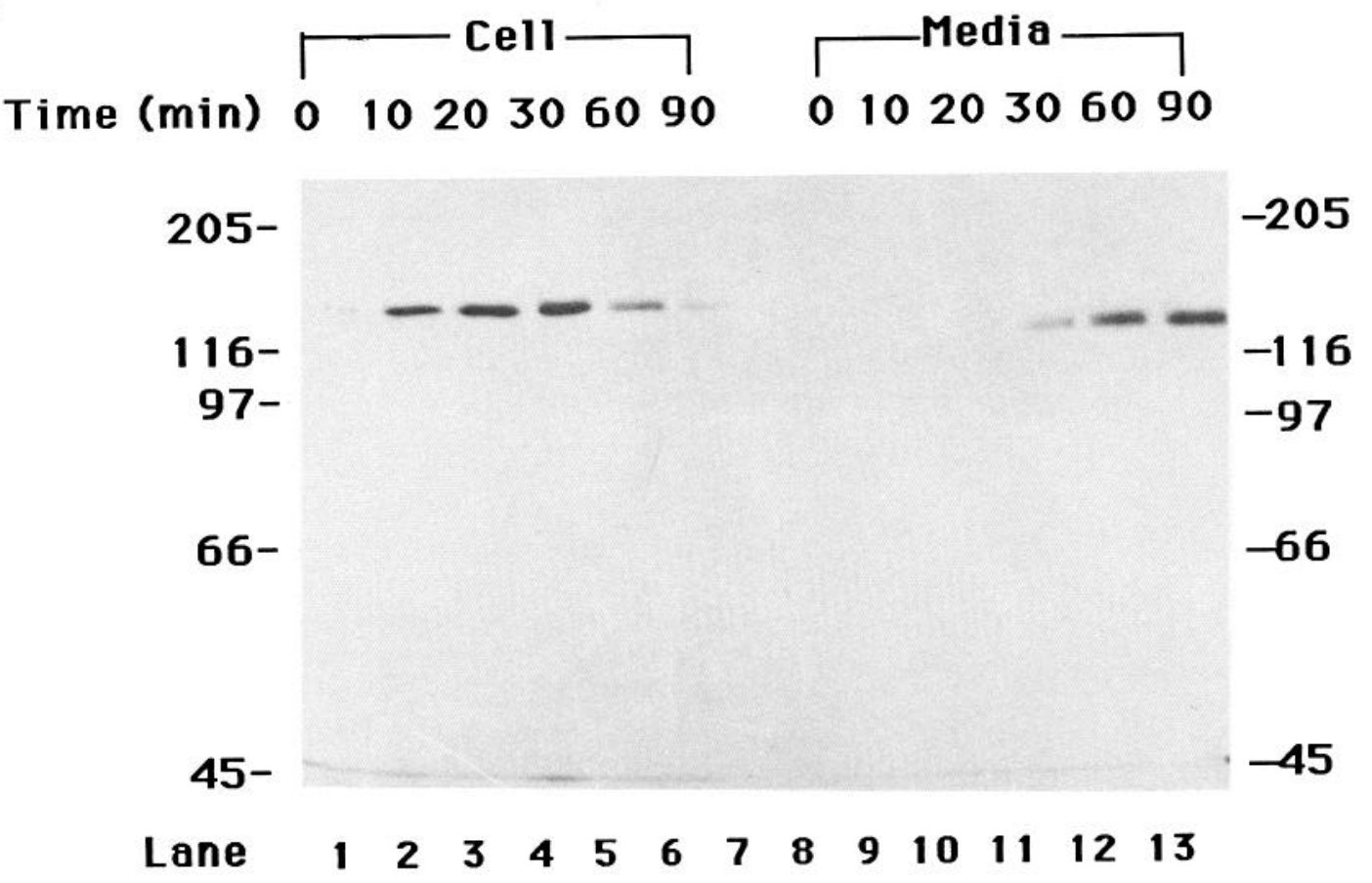

B

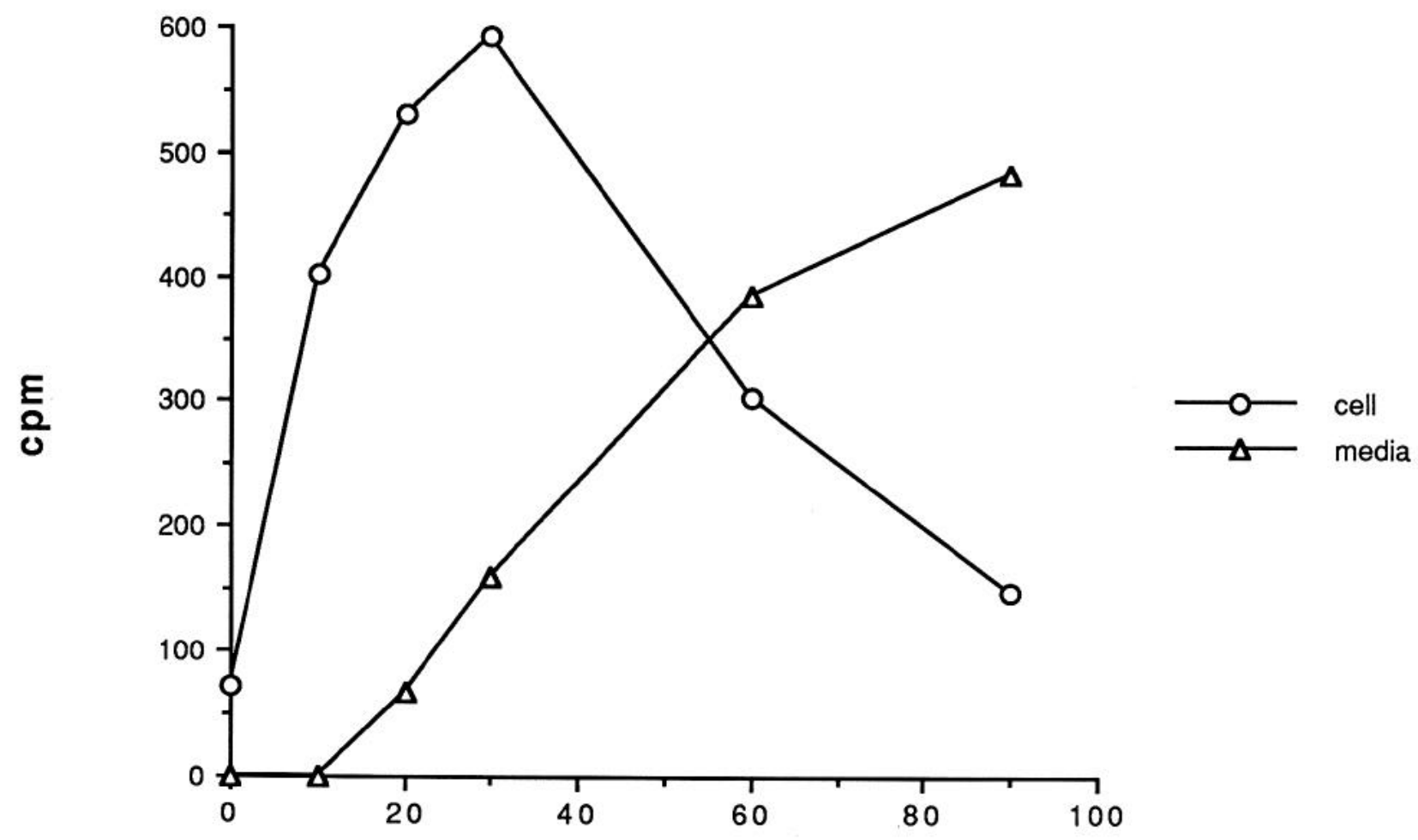

Time (min)

Figure 5. Pulse-chase labeling study of APPL in S2-Appl cells. A, S2-Appl cells were labeled with ${ }^{35}$ S-(met, cys) for 10 min and chased for $0-90$ min in complete M3 media. Cell lysates (lanes 1-6) and media (lanes 8-13) were immunoprecipitated with $\alpha$-APPL. Lane 7 is blank. B, Quantitative analysis of pulse-chase labeling of the same gel as in $A$ with Ambis radioanalytic imaging system. Circles represent the cpm of cell lysate points, and triangles represent the cpm of media points. 


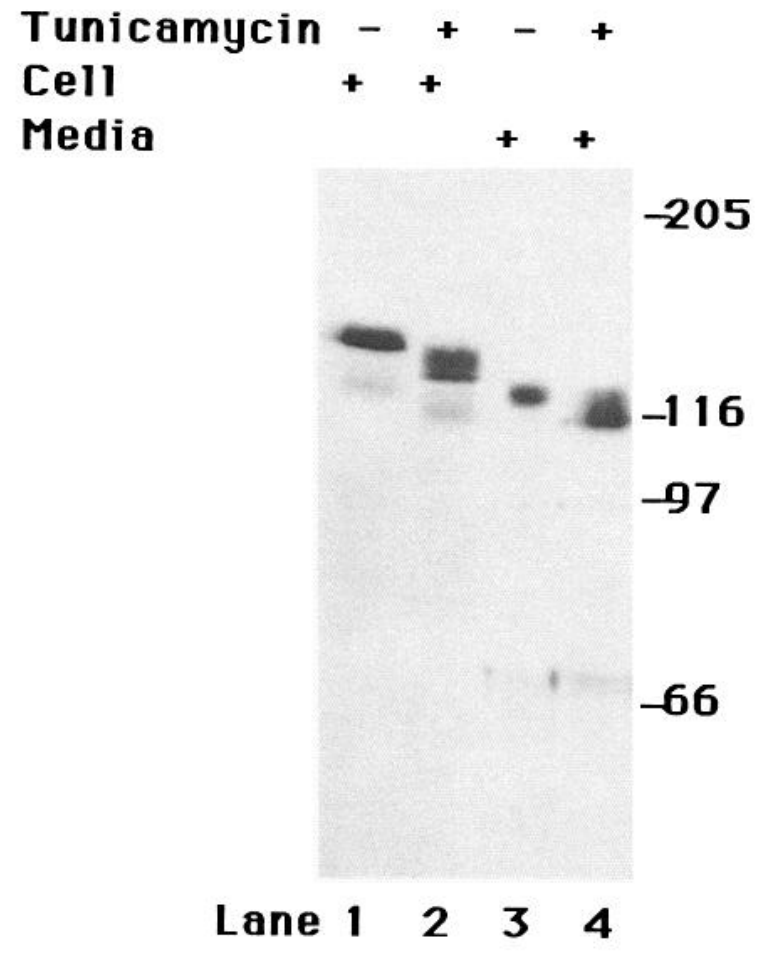

Figure 6. Both $145-\mathrm{kDa}$ and $130-\mathrm{kDa}$ forms are N-glycosylated. S2Appl cells were labeled with ${ }^{35} \mathrm{~S}$-(met, cys) for $2 \mathrm{hr}$ in the absence (lanes $l$ and 3 ) and presence (lanes 2 and 4 ) of $10 \mu \mathrm{g} / \mathrm{ml}$ tunicamycin. The cell lysates (lanes 1 and 3 ) and culture media (lanes 2 and 4 ) were immunoprecipitated with $\alpha$-APPL serum. Compared with lanes 1 and 3 , in lanes 2 and 4, there are apparent molecular-weight decreases for APPL proteins, indicating the inhibition of $\mathrm{N}$-glycosylation.

\section{Both the precursor and the secreted forms of APPL are} $N$-glycosylated

Studies of mammalian systems have shown that APP is both $\mathrm{N}$ - and O-glycosylated (Weidemann et al., 1989). Sequence comparison has revealed a conserved $\mathrm{N}$-glycosylation site between APP and APPL (Rosen et al., 1989). In order to test whether APPL is also N-glycosylated, S2-Appl cells were metabolically labeled after heat-shock in the presence of $10 \mu \mathrm{g} / \mathrm{ml}$ tunicamycin, which is an N-glycosylation inhibitor. Both the precursor and the secreted forms have apparent-molecular-weight shifts in the presence of tunicamycin (Fig. 6, cf. lanes 1, 3 with lanes $2,4)$, suggesting that APPL is N-glycosylated, and that the inhibition of N-glycosylation does not prevent the formation of the secreted form. Similar molecular-weight shifts were observed in metabolically labeled primary embryonic cells in the presence of tunicamycin (data not shown).

\section{APPL is expressed in differentiated neurons}

Next, we studied the distribution of APPL during Drosophila development. The Appl transcript is restricted to the nervous system (Martin-Morris and White, 1990); however, the protein distribution may differ in light of its secretion. Affinity-purified $\alpha$-APPL was used for immunocytochemical studies in embryonic stages. Staining above background is first detected at stage 13 (Campos-Ortega and Hartenstein, 1985), when germ-band shortening is complete and axonogenesis starts (Jacobs and Goodman, 1989; data not shown). The staining increases with age and persists throughout embryonic development (data not shown), which is consistent with the developmental immunoblot (Fig. 2A) and RNA analysis (Rosen et al., 1989; MartinMorris and White, 1990). APPL immunoreactivity is restricted to, and present throughout, the CNS and PNS during embryonic stages (Fig. 7A), both in cortical and neuropil regions (Fig. 7A,C). In particular, the axon tracts are heavily stained, as can be seen in the central commissures of the brain lobes (Fig. $7 \mathrm{~B}$ ) and in the longitudinal and transverse commissures of the ventral cord (Fig. $7 A, C$ ). Through all sections of the embryo, no immunoreactivity was detected outside the CNS and PNS (Fig. $7 B, C$ ), though this does not exclude the possibility that there might be very low levels of APPL elsewhere.

By staining whole-mount third-instar larval nervous systems and imaginal disks, APPL protein is detected in the third-instar larval brain and ventral ganglion (data not shown). APPL immunoreactivity is also present in eye disks. Figure $7 D$ shows APPL expression pattern in developing photoreceptor cells in eye disks. APPL immunoreactivity is present in cells posterior to the morphogenetic furrow, which indicates the border between differentiated and undifferentiated neurons (Ready et al., 1976), and in the bundle of photoreceptor axons in the optic nerve. Furthermore, there is a clear gap of several columns between the morphogenetic furrow and cells with APPL immunoreactivity. This gap might correspond to preclustered cells between the morphogenetic furrow and mature photoreceptor clusters (Ready et al., 1976). These observations are consistent with the in situ analysis of the $\mathrm{Appl}$ transcript (Martin-Morris and White, 1990) and clearly demonstrate that, in this region where neuronal differentiation events are well documented, APPL is expressed only in differentiated neurons.

To address the specificity of the affinity-purified $\alpha$-APPL serum, immunostaining was carried out on a population of embryos from a genetic cross in which $1 / 4$ of the total would consist of embryos hemizygous for a deletion that includes the $\mathrm{Appl}$ gene (see Materials and Methods). In this population, $1 / 4$ of the embryos should lack APPL immunoreactivity. Indeed, 27.6\% (78 of 283) embryos showed no staining. Figure $7 C$ depicts an APPL ${ }^{-}$embryo along with its $\mathrm{APPL}^{+}$sibling, strongly suggesting that APPL immunoreactivity is associated with the Appl gene product.

\section{Subcellular localization of $A P P L$}

Because APPL is synthesized as a membrane precursor and converted into a secreted form, it will be of interest to determine the subcellular localization of APPL protein. Relative to the small size of Drosophila neurons, salivary glands consist of large cells ideal for subcellular localization studies (Vincent et al., 1989). As APPL expression is restricted to the nervous system, we made use of a transformant line that is homozygous for 2 P-elements bearing the hsp70- $A p p l$ cDNA construct (see Materials and Methods). After heat-shock induction, ubiquitous expression of APPL should be achieved (Lis et al., 1983), including expression in salivary glands.

Salivary glands from third-instar larvae of Drosophila melanogaster are composed of large cells; some can be as large as $50 \mu \mathrm{m}$ (Fig. 8A). While salivary glands from heat-shocked wildtype third-instar larvae did not show APPL immunoreactivity (Fig. $8 B$; cf. phase-contrast photomicrograph in Fig. $8 A$ ), salivary glands from hsp- $A p p l$ transformants showed strong staining (Fig. 8C). APPL immunoreactivity is strongest surrounding the nuclear region and extending outwards, reminiscent of endoplasmic reticulum (ER) and Golgi apparatus localization (Fig. 


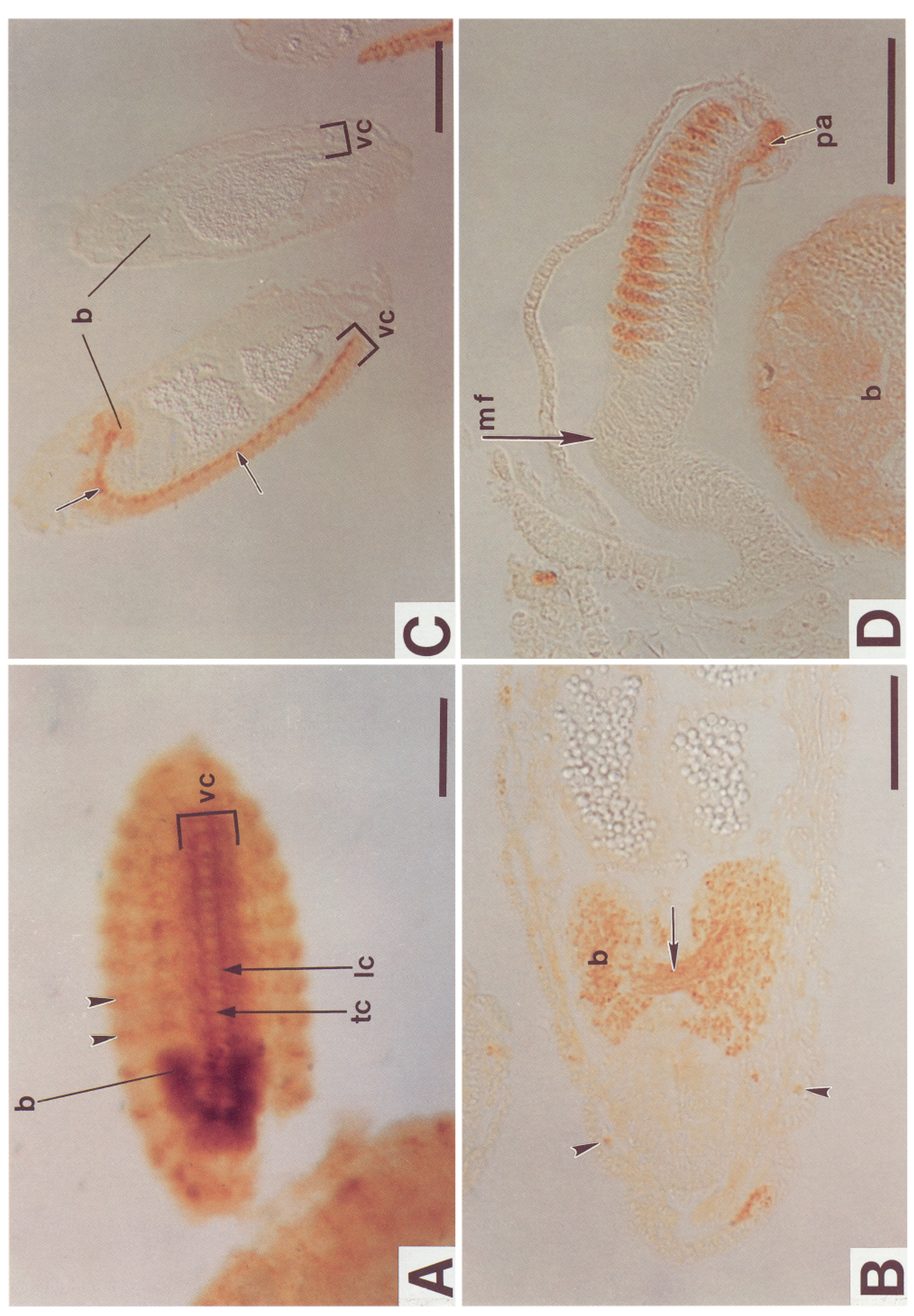

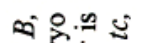
割象 正类

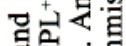
क安它 它 듕 ․ㅗ웜음

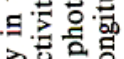
웡 는 을 음 일 궁요 目完吉 且出要要 安 5 น 究鄙 ㅇ요료 동흘 E्ञ

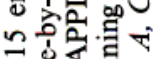
踏焉

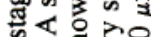

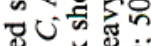
的落 जै है용

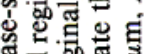
공 ํํํ ํㅝำ 造宓空

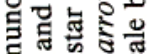
즐 ․ํำ

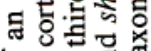

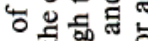

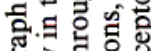

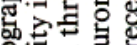
논 흔하

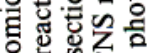
용 壵。

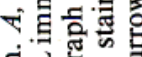

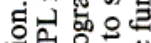

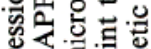
믕 믕 중웡

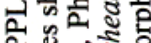

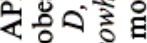
ช. 춘 可记安

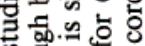
흐ㅇㅛㅛ전 논웛

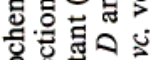

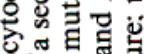
ชั 응 궁류 트웜ㅇㅇㅇ . 人寻它密

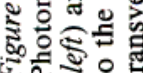




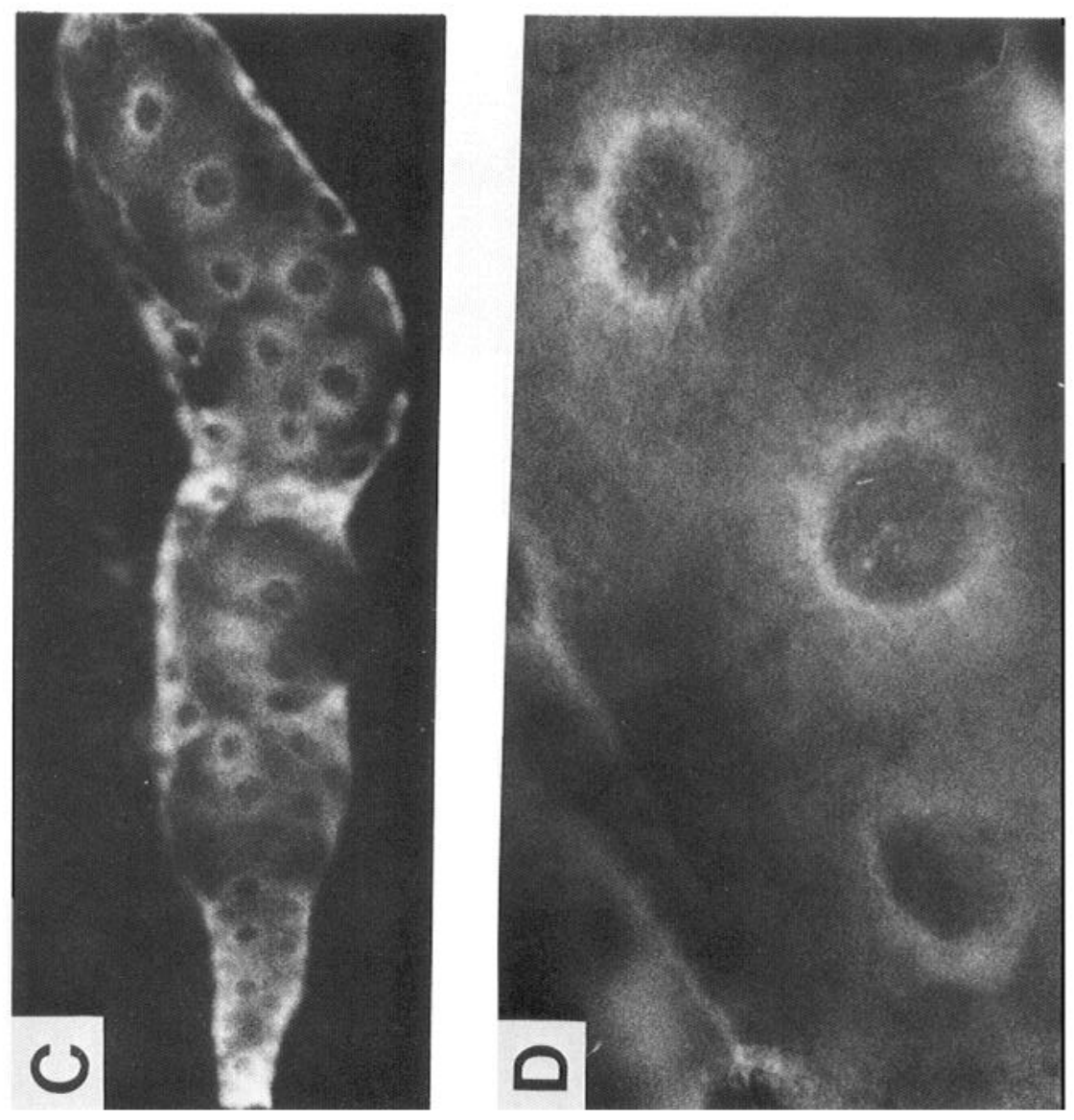

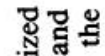

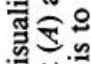

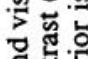

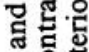

ती

讨

过语。

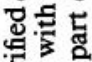

矿客

i.

.

完.

을

定



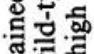

5

छी

啶

무

해음

证.

空

을

눙

을

唯

s.

在

운융ㅎㅀ

की

등 on
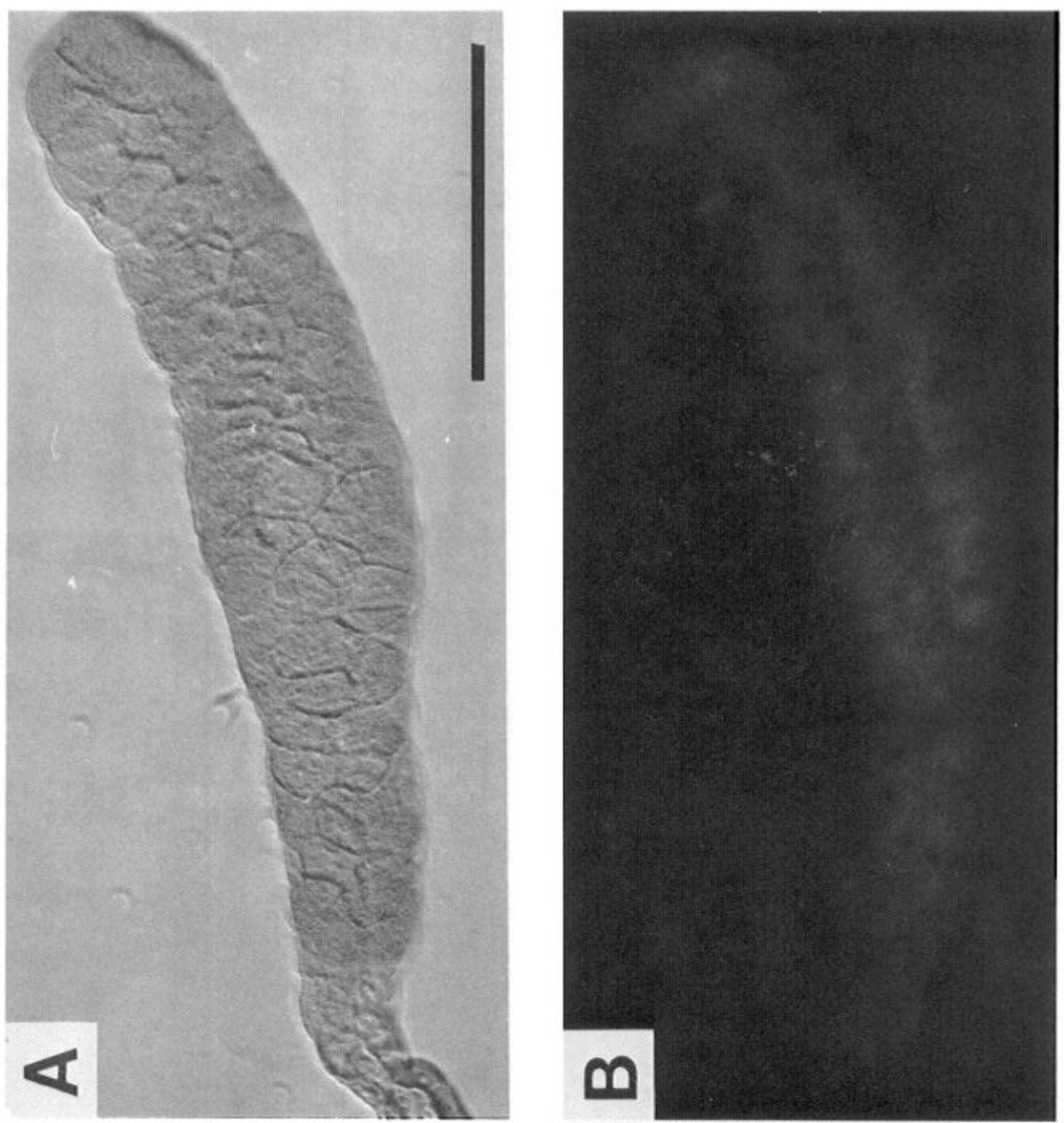

艛

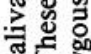

ก็ ำ

एक

70

की

8 岤

틍흥

옹

동

용ㅎㅀ 땡

낭

D正。

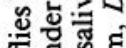
可

든

مิ

屯륭

동요

궁

물

ठु ठै स्

혀읕

要识

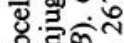

ज马

जu

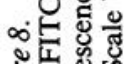

5

运责家 
$8 D$; Lippincott-Schwartz et al., 1990). No strong signal is visible at the cellular border (cf. Vincent et al., 1989). These findings, admittedly in non-ncuronal cells, are nevertheless compatible with the above biochemical analyses of APPL, indicating that APPL is synthesized as a membrane protein, but is rapidly converted to a secreted form.

\section{Discussion}

\section{Identification of APPL proteins}

Several criteria suggest that the $145-\mathrm{kDa}$ and $130-\mathrm{kDa}$ forms are the major products of $\mathrm{Appl}$. First, both forms start to appear on developmental immunoblots from 9-12-hr embryos and continue throughout embryogenesis (Fig. $2 A$ ), consistent with the expression pattern of the Appl transcript (Rosen et al., 1989). Second, both forms show enrichment using an affinity-purified $\alpha$-APPL antibody compared to serum (cf. Fig. $2 A$ with $B$ ). Third, the antibody was demonstrated to specifically recognize an antigen derived from the genomic region where $A p p l$ is located (Fig. 7C). Finally, in embryonic culture cells and in Schneider cells transfected with hsp-Appl, 2 bands comigrating with the embryonic bands on SDS-PAGE gels are observed (Figs. $3 B$, $4 A$ ). Especially in the case of S2-Appl cells, the 2 bands are specific for transfected cells (Fig. 4A, cf. lanes 1, 3 with lanes 2 , 4) and are heat inducible (cf. lane 2 with lane 4 ), as would be predicted from the construct used for transfection. This strongly suggests that the 2 forms are derived from the $\mathrm{Appl}$ transcript. Taken together, the evidence validates the identification of the $145-\mathrm{kDa}$ and $130-\mathrm{kDa}$ forms as the major $\mathrm{Appl}$ products.

\section{Biogenesis of APPL}

By using the cytoplasmic domain-specific antibody, we have subsequently shown that the $130-\mathrm{kDa}$ form in embryonic extracts lacks the cytoplasmic domain (Fig. 3A). Embryonic culture studies further demonstrate that the $130-\mathrm{kDa}$ form is secreted into the media (Fig. $3 B$ ). Studies of $\mathrm{S} 2-4 \mathrm{ppl}$ cells confirm these findings and suggest that the 2 forms are derived from the same cDNA (Fig. 4A,B). Further, fractionation of $\mathrm{S} 2-A p p l$ cells shows that the $145-\mathrm{kDa}$ protein is exclusively membrane associated, while the $130-\mathrm{kDa}$ protein is mainly in the soluble fraction (Fig. 4A, lanes 6-8). Fractionation of embryo extracts made in hypotonic solution in the absence of detergent shows a similar distribution of the 2 forms as in S2-Appl cells (data not shown). These results are consistent with the view that APPL is synthesized as a membrane-associated $145-\mathrm{kDa}$ protein, which correlates with the 886-amino acid polypeptide deduced from the cDNA sequence. It is then converted into the cytoplasmicdomain-free $130-\mathrm{kDa}$ secreted form.

Our pulse-chase experiment confirms this view and indicates that such a conversion is very rapid (Fig. 5). Most cell-surface or secretory proteins require more than $30 \mathrm{~min}$ from their synthesis on the surface of rough ER through ER, Golgi, and transporting vesicles to reach their final destiny (see, e.g., Wieland et al., 1987). In the case of APPL, while the labeled cellular protein level peaks between the 20- and 30-min chase periods (Fig. $5 B$ ), the secreted form already starts to be detected during the same period (Fig. $5 B$ ). This indicates that APPL exists as the $145-\mathrm{kDa}$ precursor only for a very short period of time before its conversion to the secreted form. The subcellular immunostaining study in large salivary glands supports this conclusion. The strongest staining is observed intracellularly, along with the pathways of membrane and secreted protein synthesis (Fig. 8D). On the other hand, cell-surface staining could not be observed, suggesting that either the $145-\mathrm{kDa}$ protein has a very transient appearance on the surface, or it has been converted to the 130$\mathrm{kDa}$ form before it reaches the cell surface. From the molecularweight difference between the 2 forms, together with the fact that the secreted form lacks the cytoplasmic domain, we propose that the $130-\mathrm{kDa}$ form could be generated by proteolytic cleavage at its extracellular domain near the membrane-spanning region.

The precise cellular compartment in which the cleavage might occur could not be clearly determined from our data. The pulsechase experiments imply that the $145 \mathrm{kDa}$ to $130 \mathrm{kDa}$ conversion happens at or very close to the cell surface, because only the 145-kDa protein band is seen associated with the cells (Fig. $5 A$ ). However, several other experiments suggest that the conversion may happen intracellularly as the secreted form is seen associated with the cells in (1) immunoblot analysis of S2-Appl cells (Fig. 4A), (2) the immunoprecipitation experiments of cells labeled for a longer duration (Fig. $4 B$, lane 1), and (3) in embryonic cell cultures (Fig. $3 B$ ). The association of the $130-\mathrm{kDa}$ form with the cells in these later situations could also be explained by specific or nonspecific binding of the secreted 130 $\mathrm{kDa}$ form to the cells when the concentration of the $130-\mathrm{kDa}$ form increases to a certain degree in the media. In light of the close relationship between the abnormal cleavage and the pathogenesis of Alzheimer's disease, the precise cleavage site and the nature of the cleavage is certainly worthy of further investigation.

Metabolic labeling of S2-Appl cells in the presence of tunicamycin, an N-glycosylation inhibitor, results in a molecular weight decrease for both forms of the APPL protein. This suggests that APPL is N-glycosylated, like its mammalian counterpart (Weidemann et al., 1989). In addition, in the presence of $10 \mu \mathrm{g} / \mathrm{ml}$ tunicamycin, which should completely inhibit the $\mathrm{N}$-glycosylation, APPL still migrates as broad bands. This result was confirmed by 3 independent experiments (data not shown). This might suggest that, in addition to $\mathrm{N}$-glycosylation, there could be other posttranslational modifications, such as O-glycosylation and tyrosine sulfation. Both of these posttranslational modifications have been demonstrated in mammalian APP studies (Weidemann et al., 1989). A point of difference in the pulse-chase and glycosylation experiments between APPL and APP is noteworthy. In the case of APP, Weidemann et al. (1989) first observed the $\mathrm{N}$-glycosylated form early in the chase period, and $\mathrm{N}$ - and $\mathrm{O}$-glycosylated form was observed later. In the case of APPL, there is no apparent molecular-weight change of the $145-\mathrm{kDa}$ form during the early chasing period. This difference may be accounted for by more pronounced temporal uncoupling of the $\mathrm{N}$-glycosylation and other modifications (O-glycosylation) in the PC-12 cells as compared to $\mathrm{S} 2$ cells.

\section{Comparison between APP and APPL}

The similarities between mammalian APP and Drosophila APPL have been extended from sequence homology (Rosen et al., 1989) to the properties of protein biosynthesis. In both cases, the proteins are synthesized as glycosylated transmembrane precursor proteins (Figs. 3-6; Weidemann et al., 1989). Secreted forms that lack the cytoplasmic domain are cleaved from the precursor and released into the media (Figs. 3-5; Palmert et al., 1989; Schubert et al., 1989a; Weidemann et al., 1989). Even the half-life of the membrane-associated precursor in pulsechase experiments appears to be similar (Fig. 5; Weidemann et al., 1989). These observations provide further evidence that 
APP and APPL might be functionally homologous in their respective organisms. In the case of secretion, the comparison is especially intriguing. There is no apparent primary sequence homology between APP and APPL in either the membranespanning region or the extracellular region bordering the membrane where the putative cleavage sites are most likely located, nor did we observe any conserved protease cleavage site. Yet, the secretion event itself is conserved. Moreover, in developing Drosophila embryos, the secreted form always coexists with the membrane-associated form (Fig. $2 A$ ). These observations strongly suggest that the secretion event is of physiological significance. In fact, secreted forms of APP in mammalian systems have been shown to produce a variety of effects (see below). Do APP and APPL function as receptors, as was initially predicted from the APP sequence structure (Kang et al., 1987), or alternatively, could the secreted form be the active form, which plays some function in the extracellular matrix or serves as a ligand? We have no direct evidence to distinguish between these 2 possibilities, but they are ccrtainly worth pursuing. If the latter case is true, then the strong homology between the cytoplasmic domain of APP and APPL could mean either that the extracellular secretion is regulated cytoplasmically, or that the remaining part, and/or the precursor, may play yet other functions.

Despite the striking similarities described above, there are apparent differences between APP and APPL. Multiple differentially spliced products have been found in APP, including 2 classes of APP that have, in the extracellular portion, an additional domain encoding a Kunitz-type protease inhibitor (Kitaguchi et al., 1988; Ponte et al., 1988; Tanzi et al., 1988). In Drosophila, a single transcript of $6.5 \mathrm{~kb}$ has been identified for $\mathrm{Appl}$ (Rosen et al., 1989), and all the protein products identified could be accounted for by a single cDNA that encodes the 886amino acid transmembrane protein (Fig. 4). Although we cannot completely rule out the possibility of the existence of multiple alternatively spliced transcripts that have similar sizes and generate different proteins of similar size, a protease inhibitor domain was not found in cDNA analyses (L. Luo and K. White, unpublished observations). Therefore, the restricted nervous system expression of the Appl transcript (Martin-Morris and White, 1990) and the APPL protein (Fig. 7) resembles an isoform of APP, APP ${ }_{695}$, which is expressed in a neural-specific fashion (Ponte et al., 1988; Neve et al., 1989; Weidemann et al., 1989) and lacks the protease inhibitor domain. Taken together, these comparisons suggest that APPL and $\mathrm{APP}_{695}$ are more similar and may represent an ancestral nervous-system function for this class of molecules. The protease inhibitor function, associated with the mammalian gene that has the ubiquitous tissue expression, may have evolved during vertebrate development. Alternatively, protease inhibitor function may have been lost during invertebrate evolution.

\section{Towards the biological function of APPL}

Immunocytochemical analysis of the APPL protein in developing embryos demonstrates that APPL expression is restricted to the nervous system, and that its onset coincides with axonogenesis. The expression pattern of APPL in developing eyes further substantiates the correlation between APPL expression and neuronal differentiation. This suggests a possible role for APPL in neural development. Various studies of mammalian APP have shed some light on its possible function. Secreted forms of APP have been shown to have growth-promoting activities on cultured fibroblasts (Saitoh et al., 1989). Fragments of APP have been implicated in either the enhancement of neuronal survival (Whitson et al., 1989) or neurotoxicity (Yankner et al., 1989). Recently, Schubert et al. (1989b) showed that, in PC-12 cells, the secretion of APP without the protease inhibitor domain $\left(\mathrm{APP}_{695}\right)$ increases upon treatment with NGF or FGF, which induces morphological differentiation of PC- 12 cells. Furthermore, the secreted form of APP could enhance the adhesion of PC-12 cells (Schubert et al., 1989b). On the basis of the similarities between APPL and APP (especially $\mathrm{APP}_{695}$ ) as discussed above, we can start to speculate on the possible roles of APPL in neuronal differentiation. The secreted form of APPL may function in developmental processes such as stimulating neurite outgrowth or helping neurite adhesion, or it may help in the maintenance of neurons. Further insights into the in vivo function of APPL shall await the mutational analysis of the Appl gene.

\section{References}

Campos-Ortega JA, Hartenstein V (1985) The embryonic development of Drosophila melanogaster. Berlin: Springer.

de Sauvage F, Octave JN (1989) A novel mRNA of the A4 amyloid precursor gene coding for a possibly secreted protein. Science 245 : 651-653.

Glenner GG, Wong CW (1984) Alzheimer's disease: initial report of the purification and characterization of a novel cerebrovascular amyloid protein. Biochem Biophys Res Commun 120:885-890.

Goldgaber D, Lerman MI, McBride OW, Saffiolli U, Gajdusek DC (1987) Characterization and chromosomal localization of a cDNA encoding brain amyloid of Alzheimer's disease. Science 235:877-880.

Harlow E, Lane D (1988) Antibodies, a laboratory manual. Cold Spring Harbor, NY: Cold Spring Harbor Laboratory.

Jacobs JR, Goodman CS (1989) Embryonic development of axon pathways in the Drosophila CNS. II. Behavior of pioneer growth cones. J Neurosci 9:2412-2422.

Kang J, Lemaire HG, Unterbeck A, Salbaum JM, Masters CL, Grzeschik KH, Multhaup G, Beyreuther K, Müller-Hill B (1987) The precursor of Alzheimer's disease amyloid A4 protein resembles a cellsurface receptor. Nature 325:733-736.

Kidd S, Baylies MK, Gasic GP, Young M (1989) Structure and distribution of the Notch protein in developing Drosophila. Genes Dev 3:1113-1129.

Kitaguchi N, Takahashi Y, Tokushima Y, Shiojiri S, Ito H (1988) Novel precursor of Alzheimer's disease amyloid protein shows protease inhibitory activity. Nature 331:530-532.

Lippincott-Schwartz J, Donaldson JD, Schweizer A, Berger EG, Hauri H-P, Yuan LC, Klausner RD (1990) Microtubule-dependent retrograde transport of proteins into the ER in the presence of Brefeldin A suggests an ER recycling pathway. Cell 60:821-836.

Lis JT, Simon JA, Sutton CA (1983) New heat shock puffs and $\beta$-galactosidase activity resulting from transformation of Drosophila with an hsp70-lacZ hybrid gene. Cell 35:403-410.

Luo L, Martin-Morris L, White K (1989) Temporal and spatial distribution of a Drosophila protein which resembles $\beta$-amyloid precursor. Soc Neurosci Abstr 15:1375.

Martin-Morris LE, White K (1990) The Drosophila transcript encoded by the $\beta$-amyloid protein precursor-like gene is restricted to the nervous system. Development, in press.

Masters CL, Simms G, Weinman NA, Multhaup G, McDonald BL, Beyreuther K (1985) Amyloid plaque core protein in Alzheimer disease and Down syndrome. Proc Natl Acad Sci USA 82:4245-4249.

Müller-Hill B, Beyreuther K (1989) Molecular biology of Alzheimer's disease. Annu Rev Biochem 58:287-307.

Neve RL, Finch F.A, Dawes IR (1988) Expression of the Alzheimer amyloid precursor gene transcripts in the human brain. Neuron 1: 669-677.

Palmert MR, Podlisny MB, Witker DS, Oltersdorf T, Younkin LH, Selkoe DJ, Younkin SG (1989) The $\beta$-amyloid protein precursor of Alzheimer disease has soluble derivatives found in human brain and cerebrospinal fluid. Proc Natl Acad Sci USA 86:6338-6342.

Pirotta V (1988) Vectors for P-mediated transformations in Drosophila. In: Vectors: a survey of molecular cloning vectors and their uses 
(Rodriguez RL, Reinhardt DT, eds), pp 437-456. Boston: Butterworths.

Ponte P, Gonzalez-DeWhitt P, Schilling J, Miller J, Hsu D, Greenberg B, Davis K, Wallace W, Lieberburg I, Fuller F, Cordell B (1988) A new A4 amyloid mRNA contains a domain homologous to serine proteinase inhibitors. Nature 331:525-527.

Ready DF, Hanson TE, Benzer S (1976) Development of the Drosophila retina, a neurocrystalline lattice. Dev Biol 53:217-240.

Rio DC, Rubin GM (1985) Transformation of cultured Drosophila melanogaster cells with a selectable marker. Mol Cell Biol 5:18331838.

Rio DC, Laski RA, Rubin GM (1986) Identification and immunochemical analysis of biologically active Drosophila $\mathrm{P}$ element transposase. Cell 44:21-32.

Robakis NK, Ramakrishna N, Wolfe G, Wisniewski HM (1987) Molecular cloning and characterization of a cDNA encoding the cerebrovascular and the ncuritic plaque amyloid peptide. Proc Natl Acad Sci USA 84:4190-4194.

Robinow S (1989) The elav gene of Drosophila melanogaster encodes a neuron-specific RNA binding protein which is required for the development and maintenance of the nervous system. $\mathrm{PhD}$ thesis, Brandeis University.

Robinow S, Campos AR, Yao K-M, White K (1988) The elav gene product of Drosophila, required in neurons, has three RNP consensus motifs. Science 242:1570-1572.

Rosen DR, Martin-Morris L, Luo L, White K (1989) A Drosophila gene encoding a protein resembling the human $\beta$-amyloid protein precursor. Proc Natl Acad Sci USA 86:2478-2482.

Rubin GM, Spradling AC (1982) Genetic transformation of Drosophila with transposable element vectors. Science 218:348-353.

Saitoh T, Sundsmo M, Roch J-M, Kimura N, Colc G, Schubcrt D, Olterdorf T, Schenk DB (1989) Secreted form of amyloid $\beta$ protein precursor is involved in the growth regulation of fibroblasts. Cell 58: 615-622.

Schubert D, LaCorbiere M, Saitoh T, Cole G (1989a) Characterization of an amyloid $\beta$ precursor protein that binds heparin and contains tyrosine sulfate. Proc Natl Acad Sci USA 86:2066-2069.

Schubert D, Jin L-W, Saitoh T, Cole G (1989b) The regulation of amyloid $\beta$ protein precursor secretion and its modulatory role in cell adhesion. Neuron 3:689-694.

Selkoe DJ (1989) Biochemistry of altered brain proteins in Alzheimer's disease. Annu Rev Neurosci 12:463-490.
Simon MA, Botwell DD, Rubin GM (1989) Structure and activity of the sevenless protein, a protein tyrosine kinase receptor required for photoreceptor development in Drosophila. Proc Natl Acad Sci USA 86:8333-8337.

Studier FW, Moffat BA (1986) Use of bacteriophage T7 RNA polymerase to direct selective high-level expression of cloned genes. J Mol Biol 189:113-130.

Tanzi RE, Gusella JF, Watkins PC, Bruns GAP, St George-Hyslop P, Van Keuren ML, Patterson D, Pagan S, Kurnit DM, Neve RL (1987) Amyloid $\beta$ protein gene: cDNA, mRNA distribution, and genetic linkage near the Alzheimer locus. Science 235:880-884.

Tanzi RE, McClatchey AI, Lamperti ED, Villa-Komaroff L, Gusella JF, Neve RL (1988) Protease inhibitor domain encoded by an amyloid protein precursor mRNA associated with Alzheimer's disease. Nature 331:528-530.

Thomas JB, Crews ST, Goodman CS (1988) Molecular genetics of the single-minded locus: a gene involved in the development of the Drosophila nervous system. Cell 52:133-141.

Vincent WS III, Gregory RJ, Wadsworth SC (1989) Embryonic expression of a Drosophila src gene: alternate forms of the protein are expressed in segmental stripes and in the nervous system. Genes Dev $3: 334-347$

Weidemann A, Konig G, Bunke D, Fischer P, Salbaum JM, Masters CL, Beyreuther K (1989) Identification, biogenesis, and localization of precursors of Alzheimer's disease A4 amyloid protein. Cell 57: 115-126.

White K, Hurteau T, Punsal P (1986) Neuropeptide-FMRFamidelike immunoreactivity in Drosophila: development and distribution. J Comp Neurol 247:430-438.

Whitson JS, Selkoe DJ, Cotman CW (1989) Amyloid $\beta$ protein enhances the survival of hippocampal ncurons in vitro. Science 243: 1488-1490.

Wieland F, Gleason ML, Serafini TA, Rothman JE (1987) The rate of bulk flow from the endoplasmic reticulum to the cell surface. Cell 50:289-300.

Wilcox M (1986) Cell surface antigens. In: Drosophila, a practical approach (Roberts DB, ed), pp 243-277. Oxford: IRL Press.

Yankner BA, Dawes LR, Fisher S, Villa-Komaroff L, Oster-Granite ML, Neve RL (1989) Neurotoxicity of a fragment of the amyloid precursor associated with Alzheimer's disease. Science 245:417-420. 